\title{
Rutin restores adenosine deaminase activity in serum and the liver and improves biochemical parameters in streptozotocin-induced diabetic rats
}

CHIELLE, E.O.1,3*; BONFANTI, G.2; DE BONA, K.S.2; CARGNELUTTI, L.O.'; BITENCOURT, P.E.R.'; DA SILVA, P.S.'; CAMPOS, M.M.A.'; MORETTO, M.B.1,2

'Universidade Federal de Santa Maria (UFSM) - Programa de Pós-Graduacção em Ciências Farmacêuticas, Departamento de Análises Clínicas e Toxicológicas, Centro de Ciências da Saúde, 97105-900 - Santa Maria, RS, Brasil. ${ }^{2}$ Universidade Federal de Santa Maria (UFSM) - Programa de Pós-Graduação em Farmacologia, Centro de Ciências da Saúde - UFSM - Santa Maria, RS, Brasil. "Universidade do Oeste de Santa Catarina (UNOESC) - Centro de Ciências da Saúde, 89900-000 - São Miguel do Oeste, SC, Brasil. *Autor para correspondência: eduardochielle@yahoo.com.br

\begin{abstract}
ADA) is a critical control point in the regulation of adenosine levels. This study aimed to investigate the effects of a polyphenolic flavonoid, rutin, on the activity of ADA in serum, the cerebral cortex, liver, kidney, and biochemical parameters in diabetic rats. The animals were divided into four groups $(n=6)$ for the following treatments: control; diabetic (streptozotocin $55 \mathrm{mg} / \mathrm{kg}$ ); diabetic with rutin (100 mg/kg/day); diabetic with glibenclamide (10 $\mathrm{mg} / \mathrm{kg} / \mathrm{day}$ ). After 30 days, ADA activity and biochemical parameters were analyzed. The ADA activity in the serum was significantly elevated in the diabetic group compared to the control group $(p<0.01)$. The treatment with rutin prevented the increase in ADA activity in the STZinduced rats when compared to control group. Our data showed that rutin reduced glucose, LDL levels, and hepatic enzymes in comparison with the control group. These results demonstrate that the increase of ADA activity observed in diabetic rats may be an important indicator of the immunopathogenesis of hyperglycemic disorders and suggest that rutin is important for regulating the enzymatic activities associated with immune, hyperglycemic, and inflammatory response in diabetes mellitus.
\end{abstract}

Keywords: rutin; adenosine deaminase activity; streptozotocin; Wistar rats; diabetes.

RESUMO: Rutina restaura a atividade da Adenosina desaminase no soro e no fígado e melhora os parâmetros bioquímicos em ratos diabéticos induzidos por estreptozotocina. AAdenosina desaminase (ADA) representa um ponto de controle crítico na regulação dos níveis de adenosina. A rutina, um flavonóide polifenólico presente em muitas plantas, foi testado para verificar a sua influência na atividade da ADA no soro, córtex cerebral, fígado rim e parâmetros bioquímicos em ratos diabéticos. Os animais foram divididos em quatro grupos cada grupo com 6 animais), tal como: controle; diabética (estreptozotocina $55 \mathrm{mg} / \mathrm{kg}$ ); diabética + rutina (100 mg/kg/dia); diabético + glibenclamida (10 mg/kg/dia). Após 30 dias foram analisadas a atividade da ADA sérica e tecidual e parâmetros bioquímicos. A atividade de ADA no soro foi significativamente elevada no grupo diabético quando comparado ao grupo controle $(p<0,01)$. O tratamento com Rutina preveniu o aumento na atividade da ADA nos ratos diabéticos, quando comparado com o grupo controle. Os resultados mostraram que a rutina reduziu a glicose, os níveis de LDL e as enzimas hepáticas, em comparação com o grupo controle. Estes resultados mostram que o aumento da atividade da ADA observado em ratos diabéticos pode ser um indicador importante da imuno-patogênese de perturbações hiperglicêmicas e sugerem que a Rutina é importante na regulação das atividades enzimáticas associadas com a resposta imunitária, hiperglicêmica e inflamatória no Diabetes mellitus.

Palavras-chave: Rutina; Atividade da adenosina-desaminase; Streptozotocin; Ratos Wistar; Diabetes. 


\section{INTRODUCTION}

Diabetes mellitus (DM) is one of the most common chronic diseases worldwide. It has been estimated that the prevalence of DM will increase from 275 million adults in 2010 to 439 million by 2030 . DM causes morbidity and mortality in the developed world, particularly vascular complications such as atherothrombosis in the coronary vessels and failure of various organs (Shaw et al.,2010).

Adenosine is a potent endogenous antiinflammatory and immunosuppressive molecule that is released from cells into the extracellular space at sites of inflammation and tissue injury (Németh et al., 2007). One key enzyme that has an important biological role in the metabolism of purine nucleosides is Adenosine deaminase (ADA), which catalyzes irreversible hydrolytic deamination of adenosine into inosine ( $\mathrm{Uz}$ et al., 2005). ADA is essential for the proliferation and differentiation of lymphoid cells (Bota et al., 2001) downregulating the biologic effects of adenosine in situ and playing a key role in normal immune function (Hong-Jun et al., 2011). Recently, we observed that the ADA activity was higher in hyperglycemia conditions (Fredholm, 2007; De Bona et al., 2010). However, the potential contribution of ADA activity in the development of diabetic condition has not been fully clarified.

In recent years, studies evidenced that a high consumption of plant-based foods such as fruit and vegetables are associated with a significantly lower risk of DM complications (Chua, 2013). Among these substances, the natural flavonoid, Rutin, a pharmacologically active phytochemical, encountered in food sources such as onions, grapes, wheat serraceno, red beans, apples, tomatoes, red wine and black tea (Hollman et al., 1996). In fact, recent studies have shown antitumor, anti-inflammatory, antidiarrhoeal, antimutagenic, immunomodulatory and hepatoprotective activities of Rutin (Schwedhelm et al., 2003).

In this context, regarding that the significant properties and the intensifying use of natural flavonoids in the control of hyperglycemia and the few studies about the important enzyme of the adenosine metabolism, ADA, in diabetic rats, the objective of the present study was to evaluate the effect of rutin on the ADA activity in serum, cerebral cortex, liver and kidney of diabetic of rats induced by streptozotocin (STZ). In addition, the serum biochemical parameters were evaluated.

\section{MATERIALS AND METHODS}

\section{Chemicals}

The Streptozotocin was procured from Sigma Chemicals Co (St. Louis, MO, USA) and adenosine from Merck, Darmstadt, Germany. The rutin $\left(\mathrm{C}_{27} \mathrm{H}_{30} \mathrm{O}_{16} 3 \mathrm{H}_{2} \mathrm{O}\right)$ and glibenclamide $\left(\mathrm{C}_{23} \mathrm{H}_{28} \mathrm{CLN}_{3} \mathrm{O}_{5} \mathrm{~S}\right)$ were obtained from DEG Importação de Produtos Químicos LTDA, São Paulo - SP Brasil. All other chemicals were of analytical grade and obtained from standard commercial suppliers.

\section{Experimental Animals}

Male Wistar rats weighing between 270 and $330 \mathrm{~g}$ were obtained from the animal house of Federal University of Santa Maria (UFSM). They were grouped and housed in poly-acrylic cages and maintained under standard laboratory conditions (temperature $25 \pm 2^{\circ} \mathrm{C}$, relative humidity $60-70 \%$ and 12-h light-dark cycles). Animals were fed with commercial rat pellet feed (Presence Nutrição Animal, São Paulo, Brazil) and water, ad libitum. Experiments were carried out according to $\mathrm{NIH}$ guidelines and all procedures were approved by the Ethics of animal research at the Federal University of Santa Maria, under protocol number 0049.0243.00008 . All efforts were made to minimize the number of animals used and their suffering.

\section{Induction of diabetes}

Diabetes was induced by a single intraperitoneal injection of STZ $(55 \mathrm{mg} / \mathrm{kg})$, made up with $0.1 \mathrm{M}$ sodium-citrate buffer $(\mathrm{pH} 4.5)$ (Kamalakkannan \& Prince, 2006). The age- matched control rats received an equivalent amount of the sodiumcitrate buffer. After STZ-induction, the animals received $5 \%$ of glucose instead of water for $24 \mathrm{~h}$ after diabetes induction in order to reduce death due to hypoglycemic shock. Blood samples were collected from the tail vein $48 \mathrm{hr}$ after STZ induction and glucose levels were measured with a portable glucometer (ADVANTAGE, Boehringer Mannheim, $\mathrm{MO}$, USA). Only animals with fasting glycaemia over $250 \mathrm{mg} / \mathrm{dL}$ were considered diabetic and used for the present study.

\section{Experimental design}

The animals were divided into four groups (6 rats per group). Group 1 (C): Control rats received $0.9 \%$ saline; Group 2 (STZ): Diabetic rats received $0.9 \%$ saline; Group 3 (STZ + Rut): Diabetic rats received Rutin (100mg/kg/ b.w./d); Group 4 (STZ + Gli): Diabetic rats received glibenclamide $(10 \mathrm{mg} /$ $\mathrm{Kg} / \mathrm{b} . w . / \mathrm{d}$ ), as a standard hypoglycaemic agent. The choice of this dose of Rutin and Glibenclamide were made on the basis of previous studies of Kamalakkannan \& Prince (2006) and were given once daily by gavage. Afterwards of 30 days, the rats were anaesthetized with pentobarbital $(35 \mathrm{mg} /$ $\mathrm{kg}$, i.p.), the blood was collected by cardiac puncture and euthanized. Also, the brains were removed and

Rev. Bras. PI. Med., Campinas, v.18, n.1, supl. I, p.273-278, 2016. 
separated into cerebral cortex and samples of the liver and kidney were rapidly dissected, weighed, washed with saline and stored in formalin. The tissues were homogenized in $50 \mathrm{mM}$ phosphate buffer $\mathrm{pH} 7.0$ for 4 minutes, centrifuged at $14000 \mathrm{xg}$ for 30 minutes and the supernatant was collected for the further studies. A group of control healthy rats received only Rutin and glibenclamide. However, no significant differences were observed in these groups compared with control group on the analyzed parameters, then, these groups were not included in this study.

\section{Laboratory analysis}

Serum was separated by centrifugation at $2000 \mathrm{rpm}$ for $10 \mathrm{~min}$ for the measures of serum glucose, Alanine Aminotransferase (ALT) and g-glutamyltransferase activity (g-GT), total cholesterol, High-Density Lipoprotein (HDL-c), triglycerides, creatinine by commercial kits (Labtest Diagnostic, MG, Brazil). Low-density Lipoprotein (LDL-C) was estimated indirectly using Fridewald's formula (Fridewald et al., 1972). ADA activities in serum and tissues were determined according to Giusti \& Galanti, (1984) based on the direct production of ammonia when ADA acts in excess of adenosine. The results were expressed in $\mathrm{U} / \mathrm{L}$ and in $\mathrm{U} / \mathrm{mg}$ protein for serum and tissue, respectively. The tissue protein content was determined according to Peterson, (1977), using bovine serum albumin as standard. Glucose levels were checked at the onset and end of treatment.

\section{Statistical analysis}

All the grouped data were analyzed by one-way analysis of variance followed by Duncan's Multiple Range Test (DMRT) using Statistica 6.0 software. Also, was used $t$ test when appropriate. Normality of parameters was carefully checked before analysis of variance. The values are mean \pm standard error of mean (S.E.M). $p$ values $\leq 0.05$ were considered as significant.

\section{RESULTS}

As expected, blood glucose onset was significantly elevated $(p<0.001)$ in all groups diabetics rats when compared with control rats. In the end of the treatment, glucose concentration of the animals of the diabetic control group remained increased levels. The diabetic animals that received Rutin or glibenclamide had reduction of $20,5 \%$ and $28,94 \%$, respectively, in the glucose levels when compared with onset treatment $(p<0.05)$ (Figure 1).

We observed a significant increase in the ADA activity in serum in the diabetic group when compared to the control group $(p<0.01)$ as shown in Table 1. Rutin reduced significant the values in serum for values close to control $(p<0.01)$, even more than glibenclamide. Moreover, no difference in ADA activity was observed in the cerebral cortex, kidney and liver of the groups analyzed (Table 1).

Table 2 shows that total cholesterol and LDL-c levels in serum of the diabetic rats treated with Rutin were significantly lower than in the diabetic

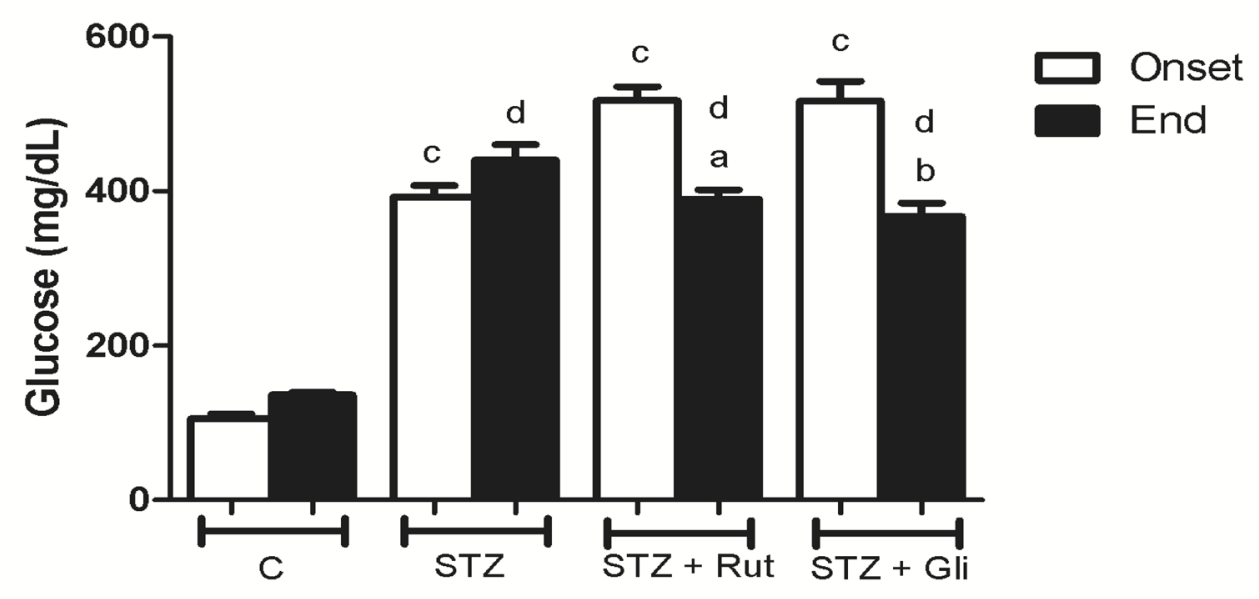

FIGURE 1.Changes in serum glucose levels $(\mathrm{mg} / \mathrm{dL})$ in onset and end treatment. Onset and End glucose of diabetic rats and treated with Rutin and Glibenclamide for 30 days. (means \pm S.E.M., $n=6$ ).

C: Control rats received $0.9 \%$ saline;

STZ: Diabetic rats;

STZ + Rut: Diabetic rats received Rutin (100mg/kg/ b.w./d);

STZ + GLI: Diabetic rats received glibenclamide $(10 \mathrm{mg} / \mathrm{Kg} / \mathrm{b} . w . / \mathrm{d})$.

a Different from the Onset STZ+ Rut (Paired t-test, $p<0.001)$;

b Different from the Onset STZ+ Gli (Paired t-test $p<0.05$ );

c Different from the C Onset (Anova followed by Duncan's test, $p<0.001$ );

d Different from the C End (Anova followed by Duncan's test, $p<0.001$ ). 
TABLE 1. ADA activity in serum (U/L), cerebral cortex, kidney and liver (U/mg protein) in normal and diabetic rats. Data from the experiments were analyzed by one-way analysis of variance (ANOVA) followed by the Duncan test to determine differences between groups (means \pm S.E.M., $n=6$ ). C: Control rats received $0.9 \%$ saline; STZ: Diabetic rats; STZ + Rut: Diabetic rats received Rutin $(100 \mathrm{mg} / \mathrm{kg} / \mathrm{b} . \mathrm{w} . / \mathrm{d}) ; \mathrm{STZ}+$ Gli: Diabetic rats received glibenclamide (10mg/Kg/b.w./d). ${ }^{a} p<0,01$ different of the $C$; ${ }^{b} p<0,05$ different of the $S T Z$; ${ }^{c} p<0,01$ different of the STZ + Rut.

\begin{tabular}{ccccc}
\hline ADA & C & STZ & STZ + Rut & STZ + Gli \\
\hline Serum & $3,36 \pm 0,45$ & $8,23 \pm 0,63^{\mathrm{a}}$ & $2,70 \pm 0,39^{\mathrm{b}}$ & $4,62 \pm 0,35^{\text {bc }}$ \\
Cerebral Cortex & $4,85 \pm 0,77$ & $5,41 \pm 0,75$ & $4,42 \pm 1,25$ & $4,45 \pm 0,69$ \\
Kidney & $49,72 \pm 5,95$ & $48,59 \pm 4,41$ & $47,26 \pm 5,24$ & $45,02 \pm 3,86$ \\
Liver & $14,60 \pm 0,35$ & $14,65 \pm 1,36$ & $14,85 \pm 0,82$ & $14,29 \pm 1,05$ \\
\hline
\end{tabular}

rats $(p<0.05$ and $p<0.01$, respectively). These values were even more significantly reduced when compared to diabetic rats treated with glibenclamide, the diabetic rats treated with Rutin had an LDL-C better than the control $(p<0.01)$. HDL-c and triglyceride concentrations remained unchanged. The treatment with Rutin showed a significant reduction $(p<0.05)$ of ALT and g-GT activities when compared to the diabetic rats. Serum concentrations of creatinine unchanged in the diabetic groups analyzed.

\section{DISCUSSION}

Hyperglycaemia is the main cause a series of biochemical events and STZ-induced diabetes in rats is a well-characterized experimental model for type 1 diabetes due to its ability to selectively destroy pancreatic islet of $\beta$-cells leading insulin deficiency
(Azkudelski, 2012). In the present study, although the ADA activity in the cerebral cortex, liver and kidney of diabetic rats were not altered, it was found that hyperglycaemia caused significant increased in the activity of ADA in serum in comparison with the control group. ADA is an important enzyme and a rise in the activity of this enzyme may lead to increased adenosine deamination, causing a reduction in the levels of this nucleoside in the circulation. Consequently, this situation may produce a favorable scenario for the development of vascular diseases in diabetic state since adenosine has an important role in the prevention of platelet aggregation and atherothrombotic complications (Schmatz et al., 2013).

The treatment with Rutin prevented the increase in the ADA activity in serum of diabetic rats after 30 days of treatment (Table 1). Presented data suggest that the possible increasing of the

TABLE 2. Biochemical profile in normal and diabetics rats. Data from the experiments were analyzed by one-way analysis of variance (ANOVA) followed by the Duncan test to determine differences between groups (means \pm S.E.M., n=6). C: Control rats received 0.9\% saline; STZ: Diabetic rats; STZ + Rut: Diabetic rats received Rutin (100mg/kg/ b.w./d); STZ + Gli: Diabetic rats received glibenclamide (10mg/Kg/b.w./d). CT: Cholesterol Total; LDL-C: LDL-cholesterol; HDL-C: HDL-cholesterol; TG: Triacylglycerols; AST: Aspartate Aminotransferase; ALT: Alanine Aminotransferase; g-GT: Gamma Glutamyltransferase; CRE: Creatinine. a $p<0,01$ different of the C; b $p<0,05$ different of the STZ; ${ }^{c} p<0,01$ different of the $S T Z+$ Rut.

\begin{tabular}{ccccc}
\hline Biochemical Parameters & C & STZ & STZ + Rut & STZ + Gli \\
\hline CT (mg/dL) & $116,3 \pm 13.91$ & $119,8 \pm 8.40$ & $91.13 \pm 3.10^{\mathrm{b}}$ & $104,3 \pm 7.43$ \\
LDL-c (mg/dL) & $31,25 \pm 8.22$ & $41,13 \pm 4.93$ & $13,75 \pm 2.09^{\mathrm{ab}}$ & $24,63 \pm 5.71^{\mathrm{b}}$ \\
HDL-c (mg/dL) & $64,25 \pm 3.58$ & $57,00 \pm 3.06$ & $54,75 \pm 1.41$ & $55,63 \pm 3.65$ \\
TG (mg/dL) & $103,3 \pm 17.95$ & $108 \pm 18.75$ & $113,5 \pm 12.13$ & $119,8 \pm 14.51$ \\
ALT (U/L) & $52,50 \pm 3.37$ & $436,0 \pm 53.17^{\mathrm{a}}$ & $227,6 \pm 41.84^{\mathrm{ab}}$ & $364,1 \pm 51.95^{\mathrm{ac}}$ \\
$\gamma-\mathrm{GT}(\mathrm{U} / \mathrm{L})$ & $5,25 \pm 0,25$ & $16,38 \pm 4.45^{\mathrm{a}}$ & $8,25 \pm 1.08^{\mathrm{b}}$ & $12,75 \pm 2.66^{\mathrm{b}}$ \\
CRE (mg/dL) & $0,78 \pm 0,02$ & $0,8 \pm 0,03$ & $0,81 \pm 0,03$ & $0,78 \pm 0,03$ \\
\hline
\end{tabular}

Rev. Bras. PI. Med., Campinas, v.18, n.1, supl. I, p.273-278, 2016. 
concentration of adenosine in the extracellular medium and suggests an interaction between Rutin and the purinergic system. These results are similar to those found in studies with other antioxidants polyphenols that also prevented the rise in ADA activity (Szudelski, 2012; De Bona et al., 2014). In fact, the decrease of the ADA activity by Rutin treatment may contribute for the adenosine level control, which may act as an endogenous activator of the cellular antioxidant defense system (De Bona et al., 2013) and of inflammatory responses and protection of tissues from injuries (Sarkhail et al., 2007).

An important aspect to be discussed in our study is that the prevention of increase of the total cholesterol by Rutin that can be associated with the hypolipidemic property exhibit by this polyphenol. In fact, Rutin significantly decreased the total cholesterol and LDL-C, a highly atherogenic molecule, although without to affect HDL-C and triglycerides of the diabetic group. Other studies have shown that Rutin displays a potential to prevent the formation of atherosclerosis and coronary heart diseases, which are severe clinical complications of diabetes (Nigdikar et al., 1998). All these events can lead to enhance local and systemic inflammations. Then, these events associated with the potential decrease of ADA activity in serum and therefore increased vascular of adenosine could suggest that Rutin plays an important role in prevention of atherosclerosis in diabetes, especially when considering the antioxidant activity of the flavonoid. Also, this property can to contribute to reduce the hepatic enzymes activity observed in the diabetic rats (Fernandes et al., 2010). These results are in accordance with other studies that have showed the hypoglycemic effects (Gandhi et al., 2011), and our findings showed the significant reduction of glucose the $20.5 \%$ end of the treatment with Rutin.

In conclusion, the results obtained in the present study demonstrate an increase in ADA activity in serum from diabetic rats indicating that purinergic system is altered in the diabetic state. Furthermore, Rutin prevented the increase in ADA activity demonstrating that this compound may modulate of purinergic responses to pathophysiological events and may consequently improve oxidative stress and inflammatory dysfunctions associated to diabetic state.

\section{ACKNOWLEDGMENTS}

The authors wish the Federal University of Santa Maria (UFSM) and University of West of Santa Catarina (UNOESC), SC, Brazil, for support in this study. M. B.Moretto is recipient of the
Conselho Nacional de Desenvolvimento Científico e Tecnológico, research fellowship(CNPq-Pq $303245 / 2014-0)$.

\section{REFERENCES}

Bota A. et al. Production and certification of an enzyme reference material for adenosine deaminase 1 (BCR 647). Clinical Chimica Acta. V.306, p.79-89, 2001.

Chua L.S. A review on plant-based Rutin extraction methods and its pharmacological activities. Journal Ethnopharmacology. v.12 n.150(3), p.805-17, 2013.

De Bona K.S. et al. Butyrylcholinesterase and Y-glutamyltransferase activities and oxidative stress markers are altered in metabolic syndrome, but are not affected by body mass index. Inflammation. v.36, n.6, p.1539-47, 2013.

De Bona K.S. et al. Syzygium cumini Extract Decrease Adenosine Deaminase, 5'Nucleotidase Activities and Oxidative Damage in Platelets of Diabetic Patients. Cell Physiology Biochemistry. 26, 729-738; 2010.

De Bona K.S. et al. Syzygium cumini is more effective in preventing the increase of erythrocytic ADA activity than phenolic compounds under hyperglycemic conditions in vitro. Journal Physiology Biochemistry. Jun;70(2):321-30, 2014.

Fernandes A.A. et al. Influence of Rutin treatment on biochemical alterations in experimental diabetes. Biomedicine Pharmacotherapy. 64(3):214-9, 2010.

Fredholm B.B. Adenosine, an endogenous distress signal, modulates tissue damage and repair. Review. Cell Death Differentiaton. 14,1315-1323, 2007.

Fridewald W.T. et al. Estimation of concentration lowdensity lipoprotein in plasma, without use od preparative ultracentrifuge. Clin chem. 18, 499-502, 1972.

Gandhi G.R. et al. Solanum torvum Swartz. fruit containing phenolic compounds shows antidiabetic and antioxidanteffects in streptozotocin induced diabetic rats. Food Chemical and Toxicology. 49(11):2725-33, 2011.

Giusti G. et al. Colorimetric method. In: Bergmeyer, H.U, Verlag Chemie, Weinheim. (Ed.). Methods of Enzymatic Analysis. 315-323, 1984.

Hollman P.C.H. et al. Analysis and health effects of favonoids. Food Chemistry, Amsterdam. 57; 1; 43-46, 1996.

Hong-Jun X. et al. Downregulation of the adenosine $a 2 b$ receptor by RNA interference inhibits hepatocellular carcinoma cell growth. International Scholarly Research Network; ISRN Oncology.1-7, 2011.

Kamalakkannan N. et al. Antihyperglycaemic and antioxidant effect of Rutin, a polyphenolic flavonoid, in streptozotocin-induced diabetic wistar rats. Basic and Clinical Pharmacology and Toxicology. 98, 97-103, 2006.

Németh Z.H, et al. Adenosine receptor activation ameliorates type 1 diabetes. The Journal of the Federation of American Societies for Experimental Biology. 21, 2379-2388, 2007.

Nigdikar S.V. et al. Consumption of red wine polyphenols reduces the susceptibility of low-density lipoproteins to oxidation in vivo. The American Journal of Clinical

Rev. Bras. PI. Med., Campinas, v.18, n.1, supl. I, p.273-278, 2016. 
Nutrition. 68, 258-265, 1998.

Peterson G.L. A simplifications of the protein assay method of Lowry et al. whigh is more gererally applicable. Analytical Biochemistry. 83, 346-356, 1977.

Sarkhail P. et al. Antidiabetic effect of Phlomisanisodonta: Effects on hepatic cells lipidperoxidation and antioxidant enzymes in experimental diabetes. Pharmacology Research. 56, 261-266, 2007.

Schmatz, R. et al. Moderate Red Wine and Grape Juice Consumption Modulates the Hydrolysis of the Adenine Nucleotides and Decreases Platelet Aggregation in Streptozotocin-Induced Diabetic Rats. Cell Biochemistry Biophysics. 65:129-143, 2013.

Shaw JE. et al. Global estimates of the prevalence of diabetes for 2010 and 2030. Diabetes Research and Clinical Practice. 87, 4-14, 2010.

Schwedhelm E. et al. Clinical pharmacokinetics of antioxidants and their impact on systemic oxidative stress. Clinical Pharmacokinet. 42, 437-459, 2003.

Szkudelski T. Streptozotocin-nicotinamide-induced diabetes in the rat. Characteristics of the experimental model. Experimental Biology and Medicine. 238, 5481-5490, 2012.

Uz E. et al. The activities of purine catabolizing enzymes and the level of nitric oxide in rat kidneys subjected to methotrexate: protective effect of caffeic acid phenethyl ester. Molecular and Cellular Biochemistry. 277, 165-170; 2005.

Rev. Bras. PI. Med., Campinas, v.18, n.1, supl. I, p.273-278, 2016. 